\title{
The Involvement of Parents in the Education of their Children in Zimbabwe's Rural Primary Schools: The Case of Matabeleland North Province.
}

\author{
Onias Mafa and Esther Makuba
}

\begin{abstract}
The study sought to explore the schools' involvement of parents in their children's education. It adopted a qualitative case study design. Data were generated from 15 primary school teachers, who were purposively sampled from three primary schools (five teachers per school). The five teachers from each school formed three focus groups. The data were triangulated by interviewing each of the three school heads from schools where teachers were sampled. Major findings were that: participants understood the meaning of parental involvement; they were aware of the benefits accruing from such an involvement; in their respective schools they were making attempts to involve parents; a number of barriers limited the effective involvement of parents. The study concluded that while teachers were aware of the benefits of parental involvement, levels of parental involvement were low. Recommendations to enhance involvement include strengthening home-school ties; equipping schools with the necessary resources to enable them to involve parents in more meaningful ways; exploring other avenues of communicating with parents and sensitising parents on the need to be actively involved in the education of their children.
\end{abstract}

Key terms: parental involvement, education, children, rural primary schools.

\section{Introduction}

The importance of parental involvement in the education of children is extensively documented. Everard, Morris and Wilson (2004) state that problems concerning behaviour and school related outcomes are easier dealt with if parents and teachers work together and there is a positive correlation between parental attitudes and their children's academic performance. In primary school science it has been observed that children learn more at home if their parents explain things to them as they go along (Peacock, 2003). Despite benefits underscoring the importance of parental involvement in their children's education, most educational interventions and innovations have ignored this educational constituency, laying emphasis on pedagogic and didactic issues. Yet as argued by Balllantine (1993:95): 'Schools have a role to play in making it possible to involve parents ... there are constructive ways to involve parents both in the education of their own children and in the school program'. As succinctly put by Every Child Matters (2003) in Peters, Seeds, Goldstein and Coleman (2007: online):

Research suggests that parenting appears to be the most important factor associated with educational achievement at age 10, which in turn is strongly associated with achievement in later life. Parental involvement in education seems to be a more important influence than poverty, school environment and the influence of peers.

Involving parents may go a long way towards early identification of children with special education needs, leading to the implementation of intervention strategies early in the children's education (Kirk et al., 2000). The nexus relationship between parents and their children's education is aptly summed by Jennings and Bosch (2011:1) who state that: 'Families are the first educators of their children and they continue to influence their children's learning and development during the school years and long afterwards'.

The aim of this study was to explore the extent of parental involvement in the education of children in Zimbabwe's rural primary schools. The study was guided by the following questions: First, what do school heads and teachers understand by the concept parental involvement? Second, what do school heads and teachers view as the importance of parental involvement? Third, how are the parents involved? Fourth, what are the barriers associated with involving parents in their children's education? Fifth, what strategies can schools use to ensure that parents are actively involved in their children's education?

\subsection{Review of Related Literature}

The importance of involving parents in the education of their children cannot be overemphasised. Pushor and Ruitenberg (2005) in Jennings and Bosch (2011:3) view parental involvement as '. . . enabling parents to take their place alongside educators in the schooling of their children, fitting together their knowledge of children, teaching and learning'. This involvement represents a shared approach to the education of children. Sharifah, Nor Jennifer and Wee Beng Neo (2001) point out that: 'The education system in the new millennium 
should encourage all schools to promote and adopt partnerships among educators, parents and families, communities, business and corporate organizations in their improvement efforts'.Bastiani (2003) identified a number of benefits accruing from involving parents in their children's education. Some of these benefits are:

- A greater willingness of parents and schools to share information and tackle misunderstandings and problems at an early stage;

- Improved levels of achievement - parents' active encouragement and support for children's learning produce tangible academic benefits that last throughout a child's school; and

- More positive pupils' attitudes and behaviour.

Desforges and Aboucher (2003) however, found that parent - child conversations in the home were more valuable, in terms of enhancing children's school achievement, than parents' involvement in school activities, suggesting that schools should encourage parents to talk to their children about school activities at home. By doubting the academic importance of parental involvement, Desforges and Aboucher could have viewed parental involvement in children's work narrowly. In our view, parent - child conversations at home about school activities are directly linked to parental involvement. For example if teachers assign homework, parents who are actively involved in their children's education are bound to talk about the homework and offer help where possible. Parental involvement must not only be viewed in terms of parents coming into the school to talk about their children or to perform certain activities. Helping their children with their homework is parental involvement.

Parental involvement in children's education creates school - family partnerships. Epstein (1992) defines education partnerships as the connections where both the school and the family recognise, respect and support each other in the children's learning process. The partnership assists in escaping the dilemma of whom to blame for the children's poor academic performance. Sharifah et al., (2001) point out that:

By working together, school and family can reinforce each other's efforts towards a common goal; and without this cooperation, neither the teacher nor the parent can be fully effective. Schools need parents and families to join them in their crusade to improve the quality of education for all students (169).

Earlier research on parental involvement in education suggests that school - family partnership should be informed by Epstein's six types of parent involvement practices (Shaifah et al., 2001; Epstein et al. 1997). The proposed model is outlined below:

\section{Type 1 - Parenting: Basic Responsibilities of Families}

This refers to the basic responsibilities of families: to ensure children's health and safety; to provide parenting and child-rearing skills needed to prepare children for school; to respond to the continued need to supervise, discipline and guide children at each age level; and to build positive home conditions that support school learning and behaviour appropriate for each grade level.

\section{Type 2 - Communication: Basic Responsibilities of Schools}

Type 2 refers to the communication from school to home about school programmes and children's progress. In the light of the school's responsibilities in this parent involvement practices, schools should design effective forms of communication so that families could be informed of the schools' programmes and children's improvement.

\section{Type 3 - Volunteer: Parent Involvement at School}

This type refers to parent volunteers who assist teachers, school heads and children in classrooms or in other school-based activities. It also refers to parents who come to school to support students' performances and sports activities; to attend workshops or other educational and training programmes; and to improve themselves so that they are able to assist their children in their learning.

\section{Type 4 - Home Involvement: Parent Involvement in Home Learning Activities}

It refers to the parent-initiated activities or child-initiated activities requests for help, and instructions from teachers for parents to monitor and assist their own children at home on learning activities that are coordinated with the children's class-work.

\section{Type 5 - School Governance: Leadership and Participation}

Type 5 refers to parents taking decision-making roles in the Parents Teachers' Associations; School Developments Committees, advisory councils, or other committees or groups at the school, district or state level. It also refers to parent and community activities in independent advocacy groups that monitor schools and work for school improvement. 


\section{Type 6-Collaboration with the Community}

Type 6 refers to school having connections with agencies, business representatives, religious groups and other groups that share responsibility for the children's education and future successes. Likewise, it refers to connections that schools, students and families contribute to the community.

\section{Research Method and Design}

The study adopted a qualitative method, where a case study research design was used. The study population consisted of teachers and school heads who were working in Matabeleland North Province in term one of 2013. Data were collected from 15 primary school teachers, who were purposively sampled from three primary schools (five teachers per school). The five teachers from each school formed a focus group. The data were triangulated by interviewing each of the three school heads from where teachers were sampled. This methodology was deemed appropriate because it afforded the researchers the opportunity to understand the phenomenon under investigation and to construct reality from the participants' perspective (Bogdan and Biklen, 1992). The researchers were also able to pursue issues and seek clarification from participants, an endeavour not possible when one employs a descriptive survey design (Gall, Borg and Gall, 1996). The focus group discussions focused on the following thematic areas:

- School heads and teachers' understanding of the concept parental involvement;

- The importance of parental involvement in their children's education;

- The school activities in which parents are usually involved;

- Challenges associated with involving parents in their children's education; and

- Suggestions on how schools can enhance parental involvement.

\subsection{Data Collection Procedure}

After receiving permission from the responsible authorities, the researchers made appointments with the respective school heads. Focus group discussions were conducted over three days. Each discussion lasted between one and half to two hours. Outcomes of the discussions were recorded verbatim using a dictaphone. After the focus group discussion in a particular school, the researchers interviewed the school head. Interviews with school heads lasted forty five minutes to one hour. After each focus group discussion and interview, outcomes were transcribed, and partially analysed (field analysis). Issues emerging from the partial analysis were pursued in the succeeding focus group discussions and interviews. When all interviews and focus group discussion outcomes were transcribed, they were taken back to the participants for verification. After verification, data were segmented, coded, enumerated and categorised into sub-themes.

\section{Findings and Discussions}

\subsection{Biodata of participants (teachers)}

\begin{tabular}{|l|l|l|l|l|l|l|l|}
\hline \multirow{2}{*}{$\begin{array}{l}\text { Focus } \\
\text { Group }\end{array}$} & \multicolumn{2}{|c|}{ Gender } & \multicolumn{2}{c|}{ Qualification } & \multicolumn{2}{c|}{ Experience } & TOTAL \\
\cline { 2 - 8 } & Male & Gender & $\begin{array}{l}\text { Diploma } \\
\text { in } \\
\text { Teaching }\end{array}$ & $\begin{array}{l}\text { Bachelor of } \\
\text { Education } \\
\text { Degree }\end{array}$ & $\begin{array}{l}6- \\
\text { years }\end{array}$ & 11 years plus & \\
\hline One & 2 & 3 & 2 & 3 & 1 & 4 & 15 \\
\hline Two & 2 & 3 & 2 & 3 & 1 & 4 & 15 \\
\hline Three & 1 & 4 & 3 & 2 & 1 & 4 & 12 \\
\hline TOTAL & 5 & 10 & 7 & 8 & 3 & 12 & \\
\hline
\end{tabular}

The sample of school heads consisted of two male and one female. All the three school heads were holders of the Bachelor of Education Degree in Educational Management. They had more than 11 years of teaching. Their headship experiences ranged between 6 and 10 years. All other things being equal, the biodata of teachers and school heads indicate that they had the requisite qualifications, teaching and school administration experiences to be able to competently discus issues pertaining to parental involvement in the education of their children.

\subsection{Teachers' understanding of the concept parental involvement}

Most participants expressed that the concept meant that parents will be playing a role in the education of their children. Three sentiments came out strongly. These sentiments are presented below.

Parents monitoring their children's education through supervision of homework: The dominant sentiment was that when parents are involved in the education of their children, they do so by assisting with the homework as well as supervising their children doing homework. Participants pointed out that schools had a mechanism where parents or guardians sign homework monitoring books after their children had completed their homework and reading assignments. 
Parents being resource persons: An appreciable number of participants pointed out that at times, parents can be used as resource persons. They explained that if in the syllabi there are topics where some parents may have expertise teachers can invite them to come to school and talk to the pupils. Examples given were parents who may be mechanics, agriculture extension workers, veterans of the war of liberation or senior citizens of the community may be invited to talk on certain topics related to their expertise.

Parents being involved in school activities: Apart from supervising and assisting with homework and acting as resource persons, involvement may also be in the form of taking part in school activities such as fundraising, assisting during sports days and other school development activities. Participants highlighted that such involvement may help reduce the gulf that may exist between schools and the community, thereby creating good working relationships between teachers, parents and guardians.

Responses from school heads on the meaning of parental involvement corroborated the teachers' views. In our view, the participants' understanding of the concept parental involvement bodes well for attempts that schools may make to engage parents in their children's education. Since school heads and teachers were aware of the meaning of parental involvement, and what parental involvement encompasses, this knowledge could be a platform to engage parents in instances where this kind of involvement is absent.

\subsection{The importance of parental involvement}

Participants in all the three focus groups agreed that parental involvement results in a number of benefits. They pointed out that benefits are likely to accrue to the pupils, their parents and the schools. Highlighted below are the benefits that were frequently mentioned by focus group participants as well as school heads who were interviewed.

Better achievement of pupils: Participants generally agreed that parental involvement results in improved academic performance. They argued that if children realise that their parents are interested and actively involved in their school work, they become motivated and work hard so as not to disappoint their parents. Some participants went on to highlight that, higher achievement may also be a result of parents monitoring and supervising homework, talking to their children about school work, giving their children ample study time at home, monitoring time spent on watching television at home, and for those with computers, monitoring the sites that their children visit. One participant pointed out that:

Parental involvement provides continuity in the learners' education. The learner does not experience a break during weekends and holidays.... The collaboration of the school and the

home in the education of a child usually yields better results and behaviour of a child.

Yet another participant reiterated: 'Parental involvement enhances quality education as their involvement will motivate children to work hard and also work together with the school to achieve organisational goals'.

Parents will know the children's strengths and weaknesses: Most participants were of the view that if parents are actively involved in the education of their children, they will become aware of the problems that their children face. As argued by one participant: . . . weaknesses are identified at early stage, e.g. pupils who are truant are identified at early stage'. Parents will have an idea of the school subjects which give their children challenges. Parents and teachers will be able to map the way forward. If there is need for extra lessons and procurement of more resource material, these interventions can be rolled out early in the child's school life, as compared to a situation where parents do not know what will be taking place at school. Some participants reiterated that, involving parents may shed light on the children's background information such as medical history. For example some children may not be performing well due to medical conditions such as Traumatic Brain Injury, which teachers may not be aware of. As rightly summed up by one of the participants: 'Parents possess first hand practical experience with their children. They know them better and their positive relationship with the teachers could help them learn better'.

Development of infrastructure: It was the sentiment of most participants that where parents are actively involved, it becomes easy for schools to develop infrastructure. The interaction that takes place when parents come into the schools, results in the creation of a symbiotic relationship. As parents come to the schools, they may also observe areas which need attention, school buildings which need repair as well as the adequacy of teaching - learning facilities. Parents will more often than not respond positively to requests to assist in developing the school, in situations where they are actively involved.

Sourcing of resources: It was generally agreed that parents who are actively involved in their children's education are aware of the schools' shortcomings in terms of educational resources. Such parents are more willing to source for extra resources, for example reading materials to augment what schools have.

Most of the views that were raised by teachers and school heads on the importance of parental involvement in children's education are corroborated by Anita (2012: online) who state that:

In addition to improving academic progress, parental involvement pays off in other significant ways. Numerous studies have shown that parents' involvement is a protective factor against adolescent tobacco use, depression, eating disorders, academic struggles, and other problems. 
By staying involved with their child and or/teenager, parents can be a source of support, create a climate for discussing tough issues and serve as role models for responsible and emphatic behaviour.

In our view, the school heads and teachers' realisations of the importance of parental involvement is very crucial for the creation of a home - school link. Where parents know that their contribution is valued, they will not hold back information that is vital to the school. Regarding children with special needs, parental involvement may furnish teachers with important information that will assist schools in coming up with early intervention strategies in order to address the child's special learning needs.

\subsection{The school activities in which parents are usually involved}

When asked the activities in which teachers involve parents apart from supervising reading and homework, participants pointed out that parents are involved during general meetings (which are usually one per term), prize giving ceremonies, and consultation or visiting days, which are held once towards the end of every term. Most participants singled out consultation or visiting days as the most effective engagement between parents and teachers. It was explained that during consultation or visiting days, parents or guardians visit schools and meet teachers of their children, parents or guardians are shown their children's writing books, and term and examination marks. In some schools, children will be present when teachers will be discussing their performance. Parents are free to seek clarification and ask for suggestions on the way forward in instances where their children will be having challenges. The following contribution from one participant captures what most participants said obtains during consultation days:

On consultation days at my school parents will be on one on one with the teacher and the pupil discussing on the achievement of the pupil where he/she is doing well and where he/she is facing challenges and then discus a way forward with the parent. The parent will have a full view of what is taking place in the education of his/her child.

Most of the activities in which schools involve parents were within Epstein's six types of parent involvement practices. In our view if parents really come go to schools during the activities referred to by teachers, most benefits alluded to by authors such as Kirk et al., (2000), Shaifah et al.,(2000) and Bastiani (2003) could be realised.

\subsection{Barriers to parental involvement}

Notwithstanding the benefits accruing from parental involvement, participants advanced a number of barriers they experienced in their attempts to involve parents. The frequently mentioned barriers were that:

Some parents lacked knowledge and were uncooperative: This barrier was identified by almost half of the participants. It was argued that such parents could not supervise their children' homework neither could they assist with the homework. The problem was that when called to come to school to discuss their children's challenges, they hardly responded positively. One participant explained that:

Parents may be called to attend to problems of their children and may not come or even refuse to come. Sour relationship between teachers and parents is a barrier that causes parents not to be free to come to school.

Most participants noted that such parents hardly attended consultation days. Teachers also realised that children of such parents struggled with their school work and most of them had disciplinary problems. However, sour relationships between some teachers and parents are a cause for concern. The participant who raised this issue was not at liberty to explain the cause of sour relationships. In our view, some teachers may look down upon parents, especially those from the low socio-economic strata. Perhaps future research should also take into cognisance how parents view their level of participation in their children's education. This may unmask how some parents feel about the way they are being treated by their children's teachers.

Time factor: This barrier was associated with working parents, cross-border traders and farming parents. Most participants explained that consultation days and general meetings were usually poorly attended due to time. Participants pointed out that during consultation days, they tell their pupils to ask their parents the time they are free to come for consultation - between 2 PM and 5 PM. Despite this flexibility, participants complained that attendance is usually low. One of the participants highlighted that:

... on consultation days, there is an element of sending maids to come and consult on the performance of pupils and that person will have no time to take note of what is transpiring at the school and all the challenges faced by the pupil.

Child-headed families: Participants mentioned that this phenomenon is increasingly becoming a problem. They pointed out that a number of children have lost their parents due to HIV/AIDS pandemic, thereby creating child-headed families. Children heading such families may not get the time to attend consultation days due to pressing problems such as working in order to put food on the table. 
Economic problems: It was also noted that some parents or guardians may fail to attend school functions due to economic problems - in that they may fail to raise the bus fare to visit the school, especially where the school is not in the neighbourhood.

Communication problems: This barrier featured in two of the three focus group discussions. It was generally felt that at times parents or guardians fail to attend school functions because of communication challenges. When asked how they communicate with parents or guardians, most participants said that they give circulars to pupils to go and give their parents. In our view, those parents who will have genuinely wanted to attend, may fail to if their children forget or deliberately forget to give them the circular. In this age of technology, we strongly feel that those schools which are not yet doing so should tap into this resource and improve communication between schools and parents.

In our opinion, these barriers are a big cause for concern. If allowed to persist unaddressed, a host of benefits that are likely to accrue to education stakeholders will be lost. For example, if the medical history of a child with special needs is not brought to the attention of the teacher because of bad blood between the teacher and the child's parents, the teacher will not know that the child has special needs. As a result, the teacher may not adapt the curriculum, teaching strategy and assessment procedure in order to accommodate the child in question.

\subsection{Suggestions on how schools can enhance parental involvement.}

Participants were requested to suggest ways for enhancing parental involvement in the education of their children. In response, participants proffered the following suggestions:

Using the print media: Participants suggested that school functions such as consultation, prize giving and general meetings could be notified to the parents and guardians through the print media. This could be used to complement circulars and newsletters. In addition, teachers could also remind their pupils to relay the message to their parents and guardians through the word of mouth.

Use of information technology: Participants were of the view that in this age of technology, schools should use emails and cell phones to communicate with their children's parents. All the schools need, is a database where contact details of pupils' parents are kept. This database needs to be updated regularly to ensure that when the need arises to communicate, the intended person will receive the information.

Availing the schools' year planners to the parents and guardians: Parents should be given the schools' year planners at the beginning of each school term. The planners should indicate dates when special events requiring parents' and guardians' presence will be held. However, owing to the forgetful nature of the human mind, schools should remind parents and guardians when the events dates draw nearer.

Sensitising parents about the need to participate in the education of their children: Some participants strongly felt that some parents do not take an active role in their children's education because they are oblivious of the impact their participation has on their children's education. Therefore, they proposed that schools schools heads, deputies, senior teachers, teachers and School Development Committees should sensitise parents on the need to participate. Participants felt that this could be achieved through meetings, emailing, sending messages through cell phones and the schools' newsletters.

Creating Open Climate: Most participants were of the view that parents resent being looked down upon and need to be respected and be shown that their contributions are valued. Therefore, the consensus among participants was that more parent participation could be enhanced by the creation of an open climate in the schools.

Have Open Channels of Communication: Participants felt that open channels of communication could enhance participation. Their opinion was that communication should not always be from school to parents schools need to listen to the parents' concerns, fears, suggestions and aspirations.

Have policies that compel parents to be involved: Participants reiterated that at times parental involvement is very low. They suggested that they should be policies that compel parents to be actively involved. However, they could not explain how the policies would be enforced. Others suggested that School Development Committees should come up with strategies to encouraged parents to attend. The interviewed school heads, acknowledged that some of the strategies suggested by teachers could increase parental involvement and pointed that they may try some of them in future. However, their concern was the financial implication of some of the strategies, for example, emailing and sending messages through the cell phones.

The number of strategies raised by teachers makes one to wonder why with such information teachers still complain of low parental turnout during certain occasions in the schools. The situation obtaining in schools is that teaching is the teachers' key result area. Communicating with parents falls under the jurisdiction of the school administration (the school head and deputy). Unless asked to give suggestions by school heads on how to address the challenge of low parental attendance, teachers may keep the suggestions to themselves. In our view, there is need for collective responsibility where teachers, school heads and deputy heads should collaborate and ensure that parents are involved in the education of their children in meaningful ways. 


\section{Conclusions and Recommendations}

The study arrived at the following conclusion: First, teachers and school heads were aware of the meaning of parental involvement. Second, they were also aware of the benefits associated with involving parents in the education their children. Third, schools were not maximising the benefits accruing from parental involvement because of a number of barriers. Fourth, teachers and school heads knew strategies that could be used to enhance parental involvement. The following recommendations are made: First, schools must be encouraged to strengthen home-school ties. Second, responsible authorities should equip schools with the necessary resources to enable them to involve parents in more meaningful ways. Third, parents need to be educated on the need for them to be actively involved in the education of their children. Fourth, future research on this phenomenon should also seek views from parents and children.

\section{References}

[1]. Anita, G. (2012). Involved parents: The hidden resource in their children's education, www.aboutourkids.org/.../involved_parents_hidden_resource... Accessed on 5 March, 2013.

[2]. Ballantine, J. H. (1993). The Sociology of Education: A Systematic Analysis (3 ${ }^{\text {rd }}$ edn.). New Jersey: Prentice - Hall, Inc.

[3]. Bastiani, J. (2003). How are schools involving parents? www.nfer.ac.uk/publication/AS001/AS001part9.pdf Accessed on 5 March 2013.

[4]. Bogdan, R. C. \& Biklen, S. K. (1992). Qualitative Research for Education: An Introduction to Theory and Methods, Boston: Allyn and Bacon.

[5]. Desforges, C. \& Aboucher, A. (2003). The Impact of Parental Involvement, Parental Support and Family Education on Pupil Achievement and Adjustment: A literature Review, Department of Education and Skills.

[6]. Epstein, J. C. (1992). School-Family-Community Partnerships: Caring for the Children We Share, Phi Delta Kappan, 76(9): 710712.

[7]. Epstein, J. C., Coates, L., Salinas, K. C., Sanders, M. G. \& Simon, B. (1997). Schools, Family and Community Partnerships: Your handbook for Action, Califronia: Corwin Press.

[8]. Everard, K. B., Morris, G. \& Wilson, (2004). Effective School Management. London: Paul Chapman Publishing.

[9]. Gall, M. D., Borg, W. R. \& Gall, J. P. (1996). Educational Research: An Introduction, $6^{\text {th }}$ ed., New York: Longman Publishers.

[10]. Kirk, S. A., Gallagher, J. J. \& Anastasiow, N. J. (2000). Educating Exceptional Children, $9^{\text {th }}$ edn., Boston: Houghton Mifflin.

[11]. Peacock, A. (2003). Teaching Primary Science. Oxford: Macmillan.

[12]. Peters, M., Seeds, K., Goldstein, A. \& Coleman, N. (2007). Parental Involvement in Children's Education, www.efln.eu/assests/pdfs/DCSF-RR034.pdf Accessed on 19 March 2013.

[13]. Sharifar, M. D., Nor Jennifer \& Wee Beng Neo (2001). Involving parents in children's education: what teachers say in Malaysia, www.ernape.net/articles/2001.NorJennifer,S.pdf Accessed 10 March 2013.

[14]. Jennings, K. \& Bosch, C. (2011). Parent engagement in children's education, Family-School and community Partnerships, Australia. 